\title{
A proposed methodology for analysing the translation of prose fiction texts with a narratively bound ironic component
}

\section{Diana Coromines i Calders}

University Pompeu Fabra

Considering literary irony as an attitude rather than a figure of speech may have some methodological advantages for the analysis of its translation. It allows us to approach the narrative universe of certain prose fiction texts as ironically determined; to select only those translated ironic passages that are narratively relevant - and thus representative; and to reach conclusions on a possible macrostructural impact. The ultimate objective of this paper is twofold: Its first aim is to present a methodology for analysing the translation of any prose fiction text, in which irony plays an essential narrative role, taking as a prime example the German novel Im Krebsgang by Günter Grass and its translations into English, Danish, Catalan and Spanish. Its second aim is to propose a provisional taxonomy of strategies used to express irony in original texts (source texts) and in translated texts (target texts).

\section{Introduction}

This paper presents a methodology for analysing the translation of literary irony. I do not mean irony in the classical, rhetorical sense of the word, but rather in the holistic sense defined by Behler (1928/1990). According to his approach, which harks back to literary modernity and Romanticism, irony is much more than a figure of speech: it is an attitude that underlies and shapes the whole literary text.

Within the limits of this study, and taking Behler's approach as my starting-point, I understand literary irony as a tacit agreement between narrator and reader. The narrator leads the reader into a tricky tangle of semantic possibilities and unexpected connotations. When (if) the reader grasps the irony, s/he has the feeling that the narrator has deliberately sent $\mathrm{him} / \mathrm{her}$ round in circles instead of guiding him/her on a straight line towards the information. But the reader obtains some compensation: s/he not only decodes the core information but receives an extra added value of surprise, unexpectedness, and even suspense.

In novels like Im Krebsgang by Günter Grass, this ironic attitude is deeply rooted in the whole narrative universe. It is ingrained in the way in which the fictional world is presented, and its frequency works as bait, inducing the reader to follow the plot in a state of constant suspense. Grass's novel is a good example of an irony-determined prose fiction text, and I will take it as the starting-point for my methodology. 


\section{Theoretical Framework}

My theoretical approach has three main features. First, it is based on the notion that a descriptive and comparative analysis at a microstructural level may generate important information about a hypothetical macrostructural impact on the translated text (Van Leuven-Zwart, 1989, 1990). Second, a methodology of the kind that I propose should provide insight into the narrative qualities of the texts analysed in order to turn an intuition (i.e., that the source text has a narratively bound ironic component) into a proven statement and to achieve a better understanding of the role that irony plays in the narrative universe of both source text and translation. For this purpose, I use Bal's research on narrative theory (1987). And third, my methodology is based on the Theory of Polyphony (Ducrot, 1989; Rubattel, 1990) in that it focuses on the narrator. My approach does not neglect the other characters, because (according to this theory) the narrator represents all the voices that appear in a text.

For the analysis of microlevel ironic passages, I take the concept of intensity as my basis. This notion is widely used today in psycholinguistics as a way to describe emotions and understand them better (Argaman, 2009). It can also be applied to the analysis of translation of irony because like emotion words and expressions, irony can usually be located on a scale depending on the intensity it expresses (Coromines i Calders, 2009) and it allows the researcher to avoid the manifold semantic shades of ironic expressions by filtering them through one single criterion.

Drawing on Coseriu's (1951/1986) distinction between language and discourse, I propose a taxonomy of irony strategies where I distinguish between "irony mechanisms" (general, abstract linguistic strategies) and "irony techniques" (more specific, discourse-bound strategies). The former are implemented through the latter.

Table 2 (section 3.3.1.) and Table 7 (3.4.1.) present an overview of the mechanisms and techniques identified in the example analysed in sections 3.3. and 3.4. I use the word instruction to refer to the different meanings (or semantic nuances, as I term them) that a specific expression may convey in a given co-text, drawing on Anscombre and Ducrot's (1983) claims that the function of discourse words differs depending on the linguistic environment in which they appear. Not all the semantic nuances included in what I call instruction correspond to what the narrator really wants to convey. The context makes it possible to identify one or more relevant semantic nuances, which I refer to as intention. The way I use this notion draws on Searle's (1990) research into the relationship existing between intention and action, which leads him to consider any action (including our use of language) as a causal and intentional transaction between mind and world. 


\section{Proposed methodology}

The methodology proposed consists of four steps: (1) prior analysis of the narrative universe of the source text, (2) selection of representative expressions of irony, (3) analysis of the selected expressions in both the source text and the translation/s and (4) evaluation of the results.

\subsection{Analysis of the narrative universe of the source text}

One way of investigating whether the source text does in fact have an irony-determined narrative universe is to carry out a narratological analysis of the kind proposed by Bal (1987). Bal's concise proposal provides the researcher with a quick idea of what the narrative universe under investigation looks like, which is actually all that is needed as a form of prior analysis.

I will briefly describe the narrative universe of Grass's Im Krebsgang at the three levels suggested by Bal (fabula, story, and text), focusing on the role played by irony at each level.

At the fabula level, Im Krebsgang has a structure determined by the main character's mother. Her behaviour leads to a series of functional (decisive) events that affect the main character (Paul) in a negative way, but the details concerning both her behaviour and its consequences are kept secret until the last chapters. In the meantime, all the reader knows of these secret events is that they have had a negative effect on the main character because he reacts to non-functional events with a bitterly ironic attitude.

At the story level, Grass organizes the chronological flow of the fabula events around flashbacks and flash-forwards. The primary narrative thread is Paul's story in the present, and from this starting-point there are constant recollections of past events that can be attributed to secondary narrative threads (e.g., the story of Wilhelm Gustloff, the story of Alexandr Marinesko, and the story of David Frankfurter). But there are also covert allusions to the closure of the novel in the form of ironic and sometimes ominous comments made by the narrator; these create suspense, as the reader lacks the information needed to fully understand them.

Finally, at the text level, irony is evident in narrative, descriptive and discursive passages. In some narrative passages, the narrator dwells on nonfunctional events as an excuse to make a critical, ironic comment about something that he disapproves of ${ }^{1}$. Descriptions are often motivated by the narrator's desire to criticize something or somebody ${ }^{2}$. Discursive passages often express a narrator's opinion indirectly, with a hidden, ironic intention that can be understood only in interaction with the co-text ${ }^{3}$.

It seems, then, that the novel Im Krebsgang has a narratively bound ironic component, and so we can proceed to the next step of the methodology. 


\subsection{Selection of representative ironic linguistic expressions}

As Bal (1987, p. 117) points out, in order to express another character's point of view, the narrator has previously sifted it through his/her own personal filters. So it follows that, from a narratological perspective, the narrator is the most important character, as Ducrot (1989) and Rubattel's (1990) Theory of Polyphony suggests.

Therefore, one efficient way of exploring the macrostructural impact of irony-dependent translation strategies is to select only the narrator's ironic passages (Coromines i Calders, 2010). And only the ones that are clearly ironic, for two reasons: those that are ambiguous may introduce noise in the data, and if they are ambiguous to the researcher, their ironic charge may remain unnoticed to the reader, and so it follows that they play a minor role in the narrative universe.

For the analysis of Im Krebsgang, I selected ten ironic passages. It is a representative choice because it reflects most directly the narrator's ironic attitude, and it leaves out expressions of irony made by other characters, which are both redundant and given less credit by the reader than those made by the narrator, because the narrator "obliges" the reader to look at the fictional world from a distanced point of view.

\subsection{Example of source-text microlevel analysis}

Table 1: Source text (Grass, 2007)

(1) Contrast between instruction and intention

positive common noun (with negative meaning)

positive idiom (with negative meaning)

positive verbs (with negative meaning)

(2) Contrast between 2 voices

Elevated style:

demonstrative pronoun

complex sentences (with multiple embedded clauses)

formal vocabulary 
Colloquial style:

complex sentences (with one embedded clause)

informal vocabulary

(3) False focalization

complex sentence (with multiple embedded clauses)

marked syntactic order

(4) Contrast between instruction and intention

polysemic descriptive adjectives (unexpected use)

common noun (unexpected use)

Da waren die drei Helden, die mir jetzt wichtig sein müssen, besser dran. Jedenfalls hat Mutter selbst nicht gewußt, wer sie geschwängert hatte, als sie mit ihren Eltern am Vormittag des 30. Januar fünfundvierzig vom Kai Gotenhafen-Oxhöft weg als Siebentausendsoundsovielte eingeschifft wurde. Derjenige, nach dem das Schiff getauft worden war, konnte einen Kaufmann, Hermann Gustloff, als Vater nachweisen. Und derjenige, dem es gelang, das überladene Schiff zu versenken, ist in Odessa, weil er als Junge einer Diebesbande angehörte, die »blatnye « geheißen haben soll, vom Vater Marinesko ziemlich oft verprügelt worden, was eine spürbar väterliche Zuwendung gewesen sein wird. Und David Frankfurter, der von Bern nach Davos reisend dafür gesorgt hat, daß das Schiff nach einem Blutzeugen benannt werden konnte, hat sogar einen richtigen Rabbi zum Vater gehabt. (Grass, 2007:22; my emphasis)

Four irony mechanisms have been identified in the source text: two cases of contrast between instruction and intention, one case of false focalization, and one contrast between two voices.

The first case of contrast between instruction and intention appears in the first sentence and is reproduced three times in the rest of the passage. It can be pinpointed for the first time in the common noun Helden ("heroes") which has a primarily positive meaning. However, in this context it can be understood only negatively since it is used to refer to three people who cannot by any means be considered "heroes". The narrator probably wants to convey the paradoxical idea that, in spite of their misfortunes, these three men had been better off than him in one thing: they 
had all had a father. By describing them as "heroes", the narrator leads the reader to decode the information indirectly, resulting in an ironic effect.

This idea is conveyed as an introduction to what is explained in more detail immediately afterwards. The contrast between instruction and intention is echoed in the idiom "jemanden nach jemandem/etwas taufen" ("er wurde nach seinem Großvater [Hermann] getauft"; "he was named [Hermann] after or for his grandfather"); the verb "gelingen" ("succeed"); and the verb "für (etwas) sorgen" ("take care of; look after sb/sth").

The positive initial sense of the three constructions is validated by the co-text: the Nazis named one of their ships after Wilhelm Gustloff as a public tribute to this martyr, Marinesko achieved a military victory by sinking the Gustloff, and Frankfurter planned his murder painstakingly. However, the context supplies the reader with further information that clashes with these positive initial connotations. He/she knows that the narrator disapproves of war and violence, and so knows that his intention is not to praise the three men. The narrator's intention is to emphasize his disapproval of them: not through blatant criticism, but by encouraging the reader to identify this criticism by him/herself, from a tangle of positive and negative connotations.

The second irony mechanism can be identified in the elevated style used by the narrator when he describes the "heroic" experiences of the three men. It can be noted in the use of the pronoun "derjenige" (the one who..."), which according to the Deutsches Universalwörterbuch is a "Verstärker" of "der" and is always followed by a relative clause, complex sentences with multiple embedded clauses and formal vocabulary: "nachweisen" ("provide information on", which according to the Oxford German Dictionary belongs to an elevated form of language) and "väterliche Zuwendung" is consistent with the first irony mechanism. Not only does the narrator describe the three men as heroes, but he imitates the language that an admirer might use to praise them.

This pompous, elevated form of language clashes with the colloquial style used by the narrator just before the description of the "heroes". It is noted through complex sentences with only one embedded clause and informal vocabulary ("besser dran"; "better off"5).

So there is a contrast between two voices: the narrator's usual voice and a fake one, imitating an elevated, grandiloquent discourse. The resulting effect is ironic because it forces the reader to deal with two opposed discourses, a task that is cognitively more challenging than dealing with a single, homogeneous voice. The reader will (hopefully) understand which voice is to be trusted, and at the same time s/he will realize that the narrator has been playing with him by not showing his cards at the outset.

The third irony mechanism overlaps with the second and fourth one. There are two elements that lead to false focalization: a complex sentence of multiple embedded clauses and a marked syntactic order. The latter can 
be pinpointed in the causal subordinate clause "weil er als Junge einer Diebesbande angehörte". This would normally go after the main clause, but here the cause comes before the predicate core. This, together with a complex sentence structure of multiple clauses, increases the sensation of suspense and obliges the reader to concentrate on what will come next (the important information): "vom Vater Marinesko ziemlich oft verprügelt worden".

On reaching this subordinate clause, the reader may feel that it is an odd piece of information to focus on. As far as the co-text is concerned, whether or not Marinesko had been beaten by his father is irrelevant. The important information here is that Marinesko had a father, a conclusion that the reader will (hopefully) reach with the help of the co-text and context the narrator does not have a father, and he repeats this at the beginning of the passage under study, when he states that the three heroes were better off than him and the next subordinate clause, where the real focus of the sentence lies: "was eine spürbar väterliche Zuwendung gewesen sein wird".

The fourth irony mechanism (again a contrast between instruction and intention) can be pinpointed in the polysemic descriptive adjectives "spürbar" ("something that can be noted by the senses" and/or "clearly showing") and "väterlich" ("father's" and/or "fatherly"), and in the common noun "Zuwendung" ("[loving] attention or care"). These three words are unexpected considering the co-text: they present the situation explained in the previous clause rather oddly as if it was the result of paternal affection. By using "Zuwendung" as a synonym for Father Marinesko's beatings, the narrator activates two semantic shades of the word: a positive one, which is unexpected given that it refers to acts of violence; and a negative one (the narrator criticizes Father Marinesko for beating his son). But neither corresponds to the narrator's intention; he does not really want either to criticize or to praise Father Marinesko's attitude.

What, then, is the narrator's intention? The common noun "Zuwendung" together with the two polysemic descriptive adjectives associated to it contribute to conveying three different semantic nuances: (1) from the narrator's point of view, the fact that Marinesko was beaten by his father was proof of paternal affection, (2) the narrator disapproves of violence, and so he does not mean it seriously and (3) number 2 is true, but from the narrator's point of view, at least Marinesko had a father; unfortunately, he cannot say the same for himself. There is only one semantic nuance that corresponds to the narrator's intention, and that is number 3. The ironic effect emerges when the reader realizes the paradoxical contrast which exists between the different semantic nuances, which results in an emphasis of the one which, according to the context, corresponds to the narrator's intention.

Table 2 shows an overview of the different irony strategies that I have just discussed. They are classified into mechanisms and techniques and defined 
without reference to the specific ironic passage shown in the above section, in order the help rationalise the analysis. Each irony mechanism in the lefthand column is matched to a number of techniques in the right-hand column.

Table 2: Original irony strategies

\begin{tabular}{|c|c|}
\hline Mechanisms (universal) & Techniques (specific) \\
\hline $\begin{array}{l}\text { Contrast between instruction and } \\
\text { intention } \\
\text { There are two or more semantic } \\
\text { nuances at play activated by the co- } \\
\text { text, and they may be slightly } \\
\text { different from each other; } \\
\text { paradoxical; or even entirely } \\
\text { contradictory. The ironic effect is } \\
\text { triggered when the reader becomes } \\
\text { aware of the contrast between the } \\
\text { narrator's intention and the rest of } \\
\text { semantic nuances (instruction). }\end{array}$ & $\begin{array}{l}\text { *Positive common noun (with } \\
\text { negative meaning) } \\
\text { The co-text activates positive and } \\
\text { negative semantic nuances of a } \\
\text { common noun, but only the negative } \\
\text { one/s correspond/s to the narrator's } \\
\text { intention. } \\
\text { *Positive idiom (with negative } \\
\text { meaning) } \\
\text { (see definition above) } \\
\text { *Positive verb (with negative } \\
\text { meaning) } \\
\text { (see definition above) } \\
\text { *Polysemic descriptive adjective } \\
\text { (unexpected use) } \\
\text { The co-text activates two or more } \\
\text { meanings of a polysemic descriptive } \\
\text { adjective, and at least one of them } \\
\text { would not be expected from the co- } \\
\text { text/the object they refer to. } \\
\text { *Common noun (unexpected use) } \\
\text { The co-text activates two or more } \\
\text { semantic shades of a common noun, } \\
\text { and at least one of them would not } \\
\text { be expected from the co-text/object } \\
\text { they refer to. }\end{array}$ \\
\hline
\end{tabular}




\begin{tabular}{|c|c|}
\hline $\begin{array}{l}\text { Contrast between } 2 \text { voices } \\
\text { There are features of two different } \\
\text { voices in the text. The reader must } \\
\text { identify which one corresponds to } \\
\text { the narrator's mindset and which } \\
\text { one is used to mock or criticize } \\
\text { somebody or something. }\end{array}$ & $\begin{array}{l}\text { *Elevated versus colloquial styles } \\
\text { In specific parts of the text there are } \\
\text { features of a colloquial style (the } \\
\text { narrator's usual voice), and in other } \\
\text { parts there are features of an } \\
\text { elevated style (an impersonated, fake } \\
\text { voice). }\end{array}$ \\
\hline $\begin{array}{l}\text { False focalization } \\
\text { The information structure is altered. } \\
\text { A piece of information is } \\
\text { highlighted to attract the reader's } \\
\text { attention, but shortly afterwards, the } \\
\text { reader is forced to focus on another } \\
\text { piece of information - the real } \\
\text { focus. }\end{array}$ & $\begin{array}{l}\text { *Marked syntactic order } \\
\text { A clause that usually appears after } \\
\text { the predicate/subject core is located } \\
\text { in the first place, thus increasing the } \\
\text { reader's feeling that important } \\
\text { information is being withheld. } \\
\text { *Complex sentence (with multiple } \\
\text { embedded clauses) } \\
\text { Small details are given first in a } \\
\text { number of embedded clauses (thus } \\
\text { increasing the degree of suspense), } \\
\text { and the predicate/subject core comes } \\
\text { only at the end. The reader has been } \\
\text { waiting for this information, so he } \\
\text { mistakenly believes that it is the } \\
\text { focus of the passage. }\end{array}$ \\
\hline
\end{tabular}

\subsection{Example of target text microlevel analysis}

Table 3: English version (Grass, 2002/2004) Irony -

(1) Reduction of contrast between instruction and intention positive common noun (with negative meaning) positive idiom (with negative meaning) positive verb (with negative meaning) 
semantic lexical shift

(2) Reduction of contrast between 2 voices

Mix of elevated and colloquial styles:

transposition of grammatical category (from demonstrative pronoun to common noun)

omission of relative pronouns

spreading of formal vocabulary

(3) Reduction of false focalization

reduction of embedded clauses

ordinary syntactic order

(4) Preservation of contrast between instruction and intention

polysemic descriptive adjectives (unexpected use)

common noun (unexpected use)

In that respect the three heroes I've been instructed to focus on were better off. It's clear, at any rate, that Mother really had no idea by whom she was pregnant when she set out on that morning of 30 January 1945 with her parents, leaving the Gotenhafen-Oxhöft pier as passenger number seven thousand such-and-such. The man for whom the ship had been named could identify a businessman, Hermann Gustloff, as his father. And as a boy in Odessa, the man who succeeded in sinking the overcrowded ship had received fairly regular beatings from Papa Marinesko - tangible proof of paternal solicitude - for belonging to a band of thieves, reportedly known as blatnye. And David Frankfurter, who travelled from Berne to Davos to set in motion the process by which the ship came to be named for a martyr, had an honest-to-goodness rabbi as his father. (Grass, 2002/2004, p. 18, my emphasis)

In the English version, the source-text irony is lessened. The first case of contrast between instruction and intention is reduced as a result of a semantic lexical shift ("set in motion"), even though the rest of the original techniques are maintained through: (1) the common noun "heroes", (2) the phrasal verb "name for" and (3) the verb "succeed". However, the verb "set 
in motion" cannot as easily be associated with a heroic attitude as the verb "für (etwas) sorgen" - which often conveys ideas like sacrifice or even an exemplary attitude. Therefore, the original consistency between this verb and the noun "heroes" is broken and the ironic contrast between instruction and intention lessened.

The second irony mechanism is also reduced. The original contrast between elevated and colloquial style gives way to an arbitrary blend of the two. First of all, relative pronouns are omitted in some of the embedded clauses: "tangible proof of paternal solicitude" (in dashes) and "reportedly known as blatnye". Second, there is a transposition: the demonstrative pronoun "derjenige" is replaced by the common noun "man". These two techniques lead to a fresher style, which lessens the elevated tone used by the source text narrator to describe the three heroes.

Third, there is a higher amount of formal vocabulary, which adds pomposity to the sentences where the heroes are described ("fairly regular beatings") but also spreads to the first sentence ("In that respect the three heroes I've been instructed to focus on"), where the original narrator consistently uses a colloquial style. As a result of this overlap of formal and informal features, the contrast between the two voices is less obvious than in the source text.

The third irony mechanism is lessened by reducing the number of embedded clauses to only one and by using an ordinary syntactic order, which allows the reader to identify the (falsely) focalized information immediately and thus reduces the suspense and the original irony. Even though there is still false focalization, the reader will not focus on it as much as the source text reader will because there is nothing to maintain the tension: s/he will probably not have the feeling that the narrator has tricked him.

The fourth mechanism is a preservation of contrast between instruction and intention, implemented through: (1) the use of two unexpected polysemic descriptive adjectives ("tangible" and "paternal") and (2) a common noun, again unexpectedly used ("solicitude").

Table 4: Danish version (Grass, 2002/2002)

Irony +

(1) Preservation of contrast between instruction and intention

positive common noun (with negative meaning)

positive prepositional verb (with negative meaning)

positive verbs (with negative meaning) 
(2) Preservation of contrast between 2 voices

Elevated style:

ordinary personal pronouns

complex sentences (with multiple embedded clauses)

formal vocabulary

Colloquial style:

complex sentences (with one embedded clause)

informal vocabulary

(3) Preservation of false focalization

complex sentence (with multiple embedded clauses)

marked syntactic order

typographical sign (dashes)

(4) Emphasis of contrast between instruction and intention

polysemic descriptive adjectives (unexpected use)

common noun (unexpected use)

addition

Så havde de tre helte, som nu skal være vigtige for mig, det bedre. I hvert fald har mor ikke selv vidst, hvem der havde gjort hende gravid, da hun sammen med sine forældre om formiddagen den 30. januar femogfyrre blev indskibet som nummer syvtusindsåogsåmange fra kajen i GotenhafenOxhöft. Han, som skibet var opkaldt efter, kunne dokumentere en far i skikkelse af købmand Hermann Gustloff. Og han, hvem det lykkedes at sænke det overlæssede skib, fik - fordi han som dreng i Odessa tilhørte en tyvebande, som skal have heddet „blatnyje” - temmelig ofte bank af Marinesko senior, hvad der uden tvivl har været en mærkbar faderlig opmærksomhed. Og David Frankfurter, som ved at rejse fra Bern til Davos sørgede for, at skibet kunne opkaldes efter et blodvidne, havde sågar en rigtig rabbiner til far. (Grass, 2002/2002, p. 20; my emphasis) 
In the Danish version, there is a slight intensification of the source-text irony. The first case of contrast between instruction and intention is maintained through: (1) the common noun "helte" ("heroes"), (2) the prepositional verb "opkalde efter" ("name for") and (3) the verbs "lykkes" ("succeed") and "sørge for" ("take care of, look after").

The second irony mechanism is also preserved. The elevated style is rendered through: (1) ordinary personal pronouns, (2) complex sentences of multiple embedded clauses and (3) formal vocabulary. Although "han" is an ordinary personal pronoun, when followed by a comma and a relative sentence it increases the pomposity of the sentence where it appears. As for the formal and elevated vocabulary, it is noted in "dokumentere" ("document") ${ }^{6}$ and "mærkbar faderlig opmærksomhed".

The colloquial style is noted in: (1) complex sentences with only one embedded clause and (2) informal vocabulary ("have det bedre"; "have it better"). Since there are clear boundaries separating the text according to the specific style used in each case, the contrast between the two different voices is maintained.

The original false focalization is implemented through: (1) a complex sentence of multiple embedded clauses; (2) a marked syntactic order and (3) a typographical sign (dashes), which allow the original marked information structure to be maintained. If it is odd to place the predicate core at the end of the sentence in German, it is even more uncommon in Danish. However, the translator manages to embed the causal subordinate clause in the middle of the sentence by placing it inside dashes. Hence, the information structure is essentially the same as in the source text.

Finally, the fourth irony mechanism is slightly intensified through an addition. Apart from the techniques used in the source text, pinpointed in: "mærkbar" ("perceptible" and/or "appreciable"), "faderlig" ("typical of a father, e.g. loving and protective" and/or "relating to a father") and "opmærksomhed" ("attention"), there is an added element: "uden tvivl" ("without (a) doubt, undoubtedly"). As a result of this addition, the contrast between instruction and intention is reinforced, because (at the word instruction level) the narrator not only considers that Marinesko's father's beatings were proof of paternal care, but states that he is completely sure of this. When the reader identifies the real intention lying behind this statement, s/he understands that: (1) the narrator by no means ("uden tvivl", undoubtedly) considers that the beatings were "paternal proof of solicitude" but (2) at the same time (again "undoubtedly"), he envies Marinesko for having had a father. 
Table 5: Catalan version (Grass, 2002/2003a)

Irony -

(1) Reduction of contrast between instruction and intention

positive common noun (with negative meaning)

positive verb (with negative meaning)

positive idiom (with negative meaning)

mutation

(2) Reduction of contrast between 2 voices

Mix of elevated and colloquial styles:

transposition of grammatical category (from demonstrative pronoun to common noun)

omission of relative pronouns

spreading of informal vocabulary

(3) Reduction of false focalization

reduction of embedded clauses

ordinary syntactic order

(4) Emphasis of contrast between instruction and intention

polysemic descriptive adjectives (unexpected use)

semantic lexical shift

Posats a fer, eren millor els tres herois, que ara seran importants per a mi. En tot cas, la mare no sabia qui l'havia deixada prenys quan el matí del 30 de gener del 44 va embarcar amb els seus pares al moll de GotenhafenOxhöft amb el número de passatgera set mil i tants. La criatura que va ser batejada amb el nom del vaixell podia assenyalar com a pare un comerciant, en Hermann Gustloff. I aquell que havia reeixit a enfonsar el 
vaixell sobrecarregat havia rebut força surres de Marinesko pare a Odessa -una mostra d'estimació paternal apreciable-perquè de petit havia format part d'una banda de lladres que es deia «Els Blatnie», 'lladregots' en rus. I en David Frankfurter, que amb el seu viatge de Berna a Davos havia fet possible que el vaixell portés el nom d'un màrtir, fins i tot havia tingut un rabí autèntic de pare. (Grass, 2002/2003a, p. 19; my emphasis)

In the Catalan version, the source-text irony is lessened. The first mechanism is reduced through mutation. Most of the techniques used are extremely similar to those identified in the source text: (1) the common noun "herois" ("heroes"), (2) the verb "reeixir" ("to succeed"), and (3) the idiom "fer possible" ("to make possible or feasible"). The narrator uses these words consistently in that their positive initial meanings are at odds with the narrator's real intention. But this consistency is broken when the source-text subject and direct object are interchanged in the translation of "jdn nach jdm/etwas taufen". The sentence "La criatura que va ser batejada amb el nom del vaixell" means literally "the child [Gustloff] that was named after the ship". Gustloff is not presented as a hero because, according to the Catalan narrator, he was named after a ship, not the other way around (which makes no sense at all in the context).

The second irony mechanism is reduced through a mix of elevated and colloquial styles. First, there is transposition: the common noun "criatura" ("child") is used instead of the pronoun "derjenige". Second, relative pronouns are omitted: the source-text clause "was eine spürbar väterliche Zuwendung gewesen sein wird" has been translated by means of the apposition "una mostra d'estimació paternal apreciable". These techniques break the pomposity used by the source-text narrator when he describes the three "heroes" and bring the style closer to the colloquial tone normally used by the narrator. The third technique also leads to a mix of elevated and colloquial style but this time it uses not formal (as in the English version) but informal vocabulary. Informal words ("surres"; "walloping", and "lladregots"; "thieves") are not just used in the first two sentences of the passage but in the description of the three men as well.

The false focalization is implemented through: (1) a reduction of embedded clauses to only one and (2) an ordinary syntactic order. The narrator reveals the predicate core at the beginning of the sentence, and so the reader of the Catalan translation does not focus on this information as much as the source-text reader does. Hence, the sensation of having been misled by the narrator is lessened, and with it also the ironic effect.

The fourth irony mechanism is slightly intensified. Apart from the two polysemic descriptive adjectives ("paternal"; "paternal" and/or "fatherly" and "apreciable"; "appreciable, considerable; noticeable" and/or "worthy, estimable, esteemed"), there is a semantic lexical shift ("estimació"; "[love] fondness, attachment, liking"). The narrator goes a step further than the source-text narrator: he considers the beatings as proof 
of love. This reinforces the contrast between instruction (Marinesko's father's beatings cannot be considered as proof of paternal love) and intention (those beatings are as valuable as love, because they mean that Marinesko had a father who, in his own way, cared for him).

Table 6: Spanish version (Grass, 2002/2003b)

Irony -

(1) Reduction of contrast between instruction and intention

positive common noun (with negative meaning)

positive verb (with negative meaning)

semantic lexical shifts

(2) Reduction of contrast between 2 voices

Colloquialization:

colloquial relative pronoun

omission of relative pronoun

(3) Preservation of false focalization

complex sentence (with multiple embedded clauses)

syntactic lexical shift

(4) Preservation of contrast between instruction and intention

polysemic descriptive adjectives (unexpected use)

common noun (unexpected use)

En eso tuvieron más suerte los tres héroes que tendrían que serme ahora importantes. En cualquier caso, Madre misma no sabía quién la había dejado embarazada cuando, con sus padres, en la mañana del 30 de enero de 1945, embarcó en el muelle de Gotenhafen-Oxhöft con el número siete mil y muchos. Aquel con cuyo nombre se bautizó el barco podía acreditar como padre a un comerciante, el señor Hermann Gustloff. $Y$ el que 
consiguió hundir el sobrecargado barco, en Odesa, como de joven perteneció a una banda de ladrones, conocida al parecer por «Blatnye» (sinvergüenzas), era azotado con cierta frecuencia por su padre Marinesko, lo que debía de ser una muestra sensible de afecto paterno. Y David Frankfurter, que, viajando de Berna a Davos, se ocupó de que se diera al barco el nombre de un «mártir», tuvo incluso como padre a un verdadero rabino. (Grass, 2002/2003b, p. 25; my emphasis)

In the Spanish version the source-text irony is also lessened. The first case of contrast between instruction and intention is implemented through: (1) the common noun "héroes", (2) the verb "conseguir" ("achieve") and (3) two semantic lexical shifts. The first shift results from the verb "bautizar" ("to baptize, to christen"). In Spanish, the positive connotations attached to "taufen nach" ("name after") can be conveyed through an idiom like "dar el nombre de". However, "bautizar" means "baptize" or "christen", which has neither positive nor negative initial connotations. The second case of semantic lexical shift results from the verb "ocuparse de" " "to deal with"; "to take interest in"; "to take care of, look after", which has a broad meaning. Since the positive connotations of these verbs (at the word instruction level) are less obvious than the ones used in the source text, the negative intention hiding behind them is also less negative, leading to a reduction of the source-text contrast.

The second mechanism is again reduced, this time as a result of colloquialization. Two techniques are used: (1) a colloquial relative pronoun; and (2) the omission of a relative pronoun. The first one ("el que") is used instead of "derjenige", and the second one leads to the apposition "conocida al parecer por «Blatnye»". These techniques bring the style of the whole passage closer to the colloquial tone used in general by the narrator. Since the elevated style is less obvious, the contrast between the two voices is reduced.

As for the false focalization, the translator maintains the source-text marked information structure through: (1) a complex sentence of multiple embedded clauses and (2) a syntactic lexical shift. By using the word "como" ("as, since") instead of "porque" ("because"), he benefits from a causal conjunction that has to be used at the beginning of the sentence. There is no longer a marked syntactic order, because the usual position of a causal clause preceded by "como" within a sentence is before the predicate core. However, the suspense that leads to an ironic effect is maintained, because all the additional details are explained first, as in the source text. Consequently, the reader will probably have the feeling that the important information is being withheld, and will be led to concentrate on it.

The fourth irony mechanism is also preserved through: (1) two polysemic descriptive adjectives: "sensible" ("sensitive" and/or "appreciable, noticeable") and "paternal" ("fatherly" and/or "paternal") and (2) a common noun: "afecto" ("affection, fondness"). 


\subsection{A taxonomy of strategies used to express irony in the target text}

Table 7 shows an overview of the irony strategies identified and analysed in the previous section, again classified into mechanisms and techniques. Note that some of the techniques are used in combination with others, but most of them can work as irony intensifiers, reducers or preservers on their own. However, in some cases the link between two or more techniques is so close that it is almost unthinkable that they can work as irony translation strategies separately. In order to indicate that a set of techniques form an (at least apparently) indivisible cluster, I use the sign (*) for the first technique described and (+) for the one/s that are used in close combination with it.

Table 7: Irony translation strategies

\begin{tabular}{|c|c|}
\hline Mechanisms (universal) & Techniques (specific) \\
\hline $\begin{array}{l}\text { Reduction of contrast between } \\
\text { instruction and intention }\end{array}$ & $\begin{array}{l}\text { *Semantic lexical shift } \\
\text { A lexical choice that entails a } \\
\text { semantic change lessens the original } \\
\text { contrast. } \\
\text { * Mutation } \\
\text { A semantic/syntactic lexical shift } \\
\text { leads to a meaning completely } \\
\text { different from the meaning } \\
\text { expressed in the source text, thus } \\
\text { lessening the original contrast. }\end{array}$ \\
\hline $\begin{array}{l}\text { Preservation of contrast between } \\
\text { instruction and intention }\end{array}$ & $\begin{array}{l}\text { *Positive common noun (with } \\
\text { negative meaning) } \\
\text { (see Table 2) } \\
\text { *Positive idiom (with negative } \\
\text { meaning) } \\
\text { (see Table 2) }\end{array}$ \\
\hline
\end{tabular}




\begin{tabular}{|c|c|}
\hline & $\begin{array}{l}\text { *Positive verb (with negative } \\
\text { meaning) } \\
\text { (see Table 2) } \\
\text { *Positive prepositional verb (with } \\
\text { negative meaning) } \\
\text { The co-text activates positive and } \\
\text { negative semantic nuances of a } \\
\text { prepositional verb, but only the } \\
\text { negative one/s correspond/s to the } \\
\text { narrator's intention. } \\
\text { *Polysemic descriptive adjective } \\
\text { (unexpected use) } \\
\text { (see Table 2) } \\
\text { *Common noun (unexpected use) } \\
\text { (see Table 2) }\end{array}$ \\
\hline $\begin{array}{l}\text { Emphasis of contrast between } \\
\text { instruction and intention }\end{array}$ & $\begin{array}{l}\text { *Addition } \\
\text { An added linguistic element } \\
\text { emphasizes the source-text contrast. } \\
\text { *Semantic lexical shift } \\
\text { A lexical choice that entails a } \\
\text { semantic change strengthens the } \\
\text { original contrast }\end{array}$ \\
\hline $\begin{array}{l}\text { Reduction of contrast between } 2 \\
\text { voices }\end{array}$ & $\begin{array}{l}\text { * Mix of elevated and colloquial } \\
\text { styles } \\
\text { Linguistic features of both styles do } \\
\text { not appear consistently in separate } \\
\text { parts of the passage but are } \\
\text { arbitrarily blended, which makes it } \\
\text { difficult to identify two different } \\
\text { voices in contrast. }\end{array}$ \\
\hline
\end{tabular}




\begin{tabular}{|c|c|}
\hline & $\begin{array}{l}\text { *Colloquialization } \\
\text { An increase in the number of } \\
\text { colloquial features lessens the source } \\
\text { text contrast. }\end{array}$ \\
\hline $\begin{array}{l}\text { Preservation of contrast between } 2 \\
\text { voices }\end{array}$ & $\begin{array}{l}\text { *Elevated versus colloquial styles } \\
\text { (see Table } 2 \text { ) }\end{array}$ \\
\hline Reduction of false focalization & $\begin{array}{l}\text { *Reduction of embedded clauses } \\
\text { The original number of embedded } \\
\text { clauses is reduced, which allows the } \\
\text { reader to attain the falsely focalized } \\
\text { information with less tension than in } \\
\text { the source text. Consequently, the } \\
\text { surprise he feels when he discovers } \\
\text { the real focus is also smaller. } \\
\text { +Ordinary syntactic order } \\
\text { The source text marked syntactic } \\
\text { order gives way to an ordinary one, } \\
\text { since the clause corresponding to the } \\
\text { predicate/subject core of the } \\
\text { sentence appears first and additional } \\
\text { details are given only later. }\end{array}$ \\
\hline Preservation of false focalization & $\begin{array}{l}\text { *Complex sentence (with multiple } \\
\text { embedded clauses) } \\
\text { (see Table } 2 \text { ) } \\
\text { +Marked syntactic order } \\
\text { (see Table } 2 \text { ) }\end{array}$ \\
\hline
\end{tabular}




\begin{tabular}{|l|l|}
\hline +Typographical sign (dashes) \\
Part of the information given in a \\
marked syntactic order is placed \\
inside dashes. \\
*Complex sentence (with multiple \\
embedded clauses) \\
(see Table 2) \\
+ Syntactic lexical shift \\
A lexical choice that entails a \\
syntactic change leads to \\
preservation of original focalization.
\end{tabular}

\subsection{Evaluation of the results}

To evaluate the scope of irony-dependent translation strategies as objectively as possible, it is necessary to outline a hypothetical scenario without any macrostructural impact. Considering the kind of text this methodology is designed to analyse, I argue that there are two kinds of scenario without any macrostructural impact: (1) a scenario with no ironydependent translation shifts in five of the ten ironic passages, and a compensation between irony-intensifying and irony-reducing shifts in the five remaining passages and (2) a scenario where no irony-dependent translation shifts are noted at all.

The second one may seem a tautology but it is worth bearing it in mind because, in the kind of text I deal with in this research, regular recurrence is more important than compensation. This is the same as saying that, for irony to be narratively bound, it has to appear regularly and consistently throughout the novel (as happens in the source text). Extreme compensation (five irony-intensifying versus five irony-reducing shifts) does not lead to narratively ingrained irony because the passages where irony is reduced are eclipsed by those where it is intensified, breaking the regularity that leads the reader to constantly ask him/herself what lies behind the narrator's ironic attitude.

The tables (see appendix) show an overview of the ten ironic passages analysed (Table 8 includes the English and Danish versions and Table 9 the Catalan and Spanish ones). The narrow column at the right of each translated passage indicates whether the source-text irony is intensified, preserved or reduced. 
The microlevel analysis of the ten selected passages (one of which was thoroughly analysed in sections 3.3. and 3.4.) has shown that none of the translations fully conforms to any of the scenarios outlined above. However, the Danish version (with five cases of preservation, four of reduction, and one of intensification) is quite close to the first scenario. Nevertheless, one intensification could hardly compensate for the four cases of reduction. Therefore, it can be argued that there is a (slight) impact on the macrostructure.

As for the other translations, they show a more significant macrostructural impact: in the English version there are five cases of reduction, four of preservation and one intensification; in the Catalan version there are again five cases of reduction, three preservations and two intensifications; and in the Spanish version there are nine cases of reduction and one preservation. In all cases this macrostructural impact - whose scale will depend on the total number of irony-dependent translation shifts identified in each version - results from a global reduction of the sourcetext irony. Thus its narrative consequence may be a less bitter, less mysterious fictional world, a less distanced relationship between reader and characters, and a decrease in the suspense felt by the reader.

\section{Conclusions}

This paper presents a methodology for analysing literary irony in translated prose fiction texts. Taking as its starting-point a conception of irony according to which literary texts are considered ironic if they are profoundly shaped by a narrative ironic component, this methodology suggests that the researcher working in this field should follow four steps.

The first is an analysis of the narrative universe of the source text to ensure that it really is irony-determined. Second, a representative set of the narrator's ironic passages must be selected. The third step is a microlevel analysis of the selected passages, and the last step is the evaluation of results in order to establish whether or not there is a macrostructural impact.

As an example of how the microlevel analysis may be carried out, I have studied an ironic passage from the novel Im Krebsgang by Günter Grass, and its translations into English, Danish, Catalan and Spanish. I have thus been able to propose a provisional taxonomy of translation strategies to express the irony found in the original, which can be built on in the future.

Furthermore, this study has shown that the notion of intensity is the most appropriate one for use as the basis on which to build the microlevel analysis of an irony-determined prose fiction text. It allows the researcher to avoid the multiple semantic shades conveyed by ironic expressions, and concentrate only on what is relevant regarding the objectives of the proposed methodology, that is, to establish whether an intensification or reduction of irony leads to a macrostructural impact. 


\section{Appendix}

Table 8: Results of the analysis (German, English, and Danish)

\begin{tabular}{|c|c|c|c|c|}
\hline ST & English & & Danish & \\
\hline 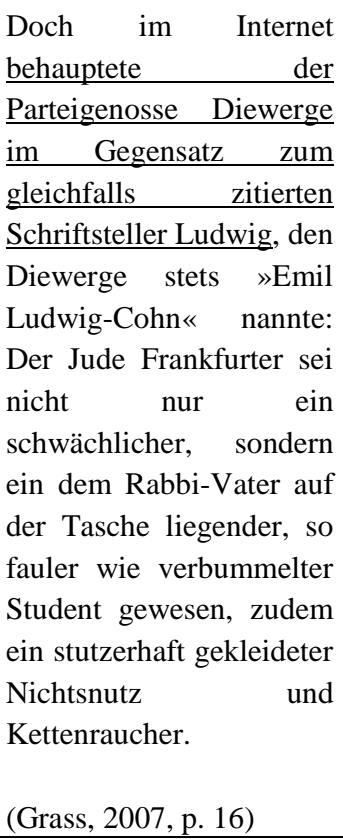 & $\begin{array}{l}\text { But Party member } \\
\text { Diewerge asserted on the } \\
\text { Internet, in contrast to } \\
\text { the writer Ludwig, whom } \\
\text { Diewerge insisted on } \\
\text { calling "Emil Ludwig- } \\
\text { Cohn", that the Jew } \\
\text { Frankfurter had been not } \\
\text { only a weakling but also } \\
\text { a lazy and shiftless } \\
\text { student, a dandy and } \\
\text { chain-smoker who } \\
\text { frittered away his } \\
\text { father's money. } \\
\text { (Grass, 2002/2004, p.11) }\end{array}$ & + & $\begin{array}{l}\text { Men på nettet påstod } \\
\text { partifælle Diewerge i } \\
\text { modsætning til den } \\
\text { ligeledes citerede } \\
\text { forfatter Ludwig, som } \\
\text { Diewerge stedse kaldte } \\
\text { „Emil Ludwig-Cohn”, } \\
\text { at jøden Frankfurter } \\
\text { havde været ikke blot } \\
\text { en svagelig, men også } \\
\text { en både doven og } \\
\text { forsumpet student, som } \\
\text { havde ligget sin } \\
\text { rabbinerfar til byrde, } \\
\text { desuden en lapset } \\
\text { døgenigt } \\
\text { kæderyger. } \\
\text { (Grass, 2002/2002, p. } \\
\text { 15) }\end{array}$ & $=$ \\
\hline $\begin{array}{l}\text { Man soll nicht } \\
\text { vergleichen. Doch was } \\
\text { das Pekuniäre betraf, ging } \\
\text { es mir bald wie David } \\
\text { Frankfurter in Bern, dem } \\
\text { der ferne Vater monatlich } \\
\text { ein Sümmchen aufs } \\
\text { Schweizer Konto legte. } \\
\text { Mutters Cousin -hab ihn } \\
\text { selig- hieß Harry } \\
\text { Liebenau, war Sohn des } \\
\text { Tischlermeisters in der } \\
\text { einstigen Elsenstraße, } \\
\text { lebte seit Ende der } \\
\text { fünfziger Jahre in Baden- } \\
\text { Baden und machte als } \\
\text { Kulturredakteur für den } \\
\text { Südwestfunk }\end{array}$ & $\begin{array}{l}\text { Comparisons are odious. } \\
\text { Yet where finances were } \\
\text { concerned, I soon found } \\
\text { myself in the same } \\
\text { situation as David } \\
\text { Frankfurter in Berne, } \\
\text { whose distant father } \\
\text { deposited a tidy sum in } \\
\text { his Swiss bank account } \\
\text { every month. Mother's } \\
\text { cousin Harry Liebenau - } \\
\text { God rest his soul- was } \\
\text { the son of the master } \\
\text { carpenter back on } \\
\text { Elsenstrasse, and had } \\
\text { been living in Baden- } \\
\text { Baden since the late } \\
\text { fifties. As the cultural }\end{array}$ & - & $\begin{array}{l}\text { Man skal ikke } \\
\text { sammenligne. Men } \\
\text { hvad det pekuniære } \\
\text { angik, gik det mig } \\
\text { snart ligesom David } \\
\text { Frankfurter i Bern, hvis } \\
\text { fjerne far hver måned } \\
\text { satte en lille sum ind } \\
\text { på hans schweiziske } \\
\text { konto. Mors fætter - } \\
\text { fred være med ham - } \\
\text { hed Harry Liebenau, } \\
\text { var søn af } \\
\text { snedkermesteren i den } \\
\text { daværende } \\
\text { Elsenstrasse, havde fra } \\
\text { sidst i halvtredserne } \\
\text { boet i Baden-Baden og }\end{array}$ & 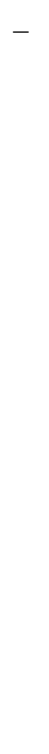 \\
\hline
\end{tabular}




\begin{tabular}{|c|c|c|c|c|}
\hline $\begin{array}{l}\begin{array}{l}\text { Nachtprogramm: Lyrik } \\
\text { gegen Mitternacht, }\end{array} \\
\text { nur nenn } \\
\text { Schwartzwaldtannen } \\
\underline{\text { zuhörten. }} \\
\\
\text { (Grass, 2007, p. 20) }\end{array}$ & $\begin{array}{l}\text { editor for Southwest } \\
\text { German Radio, he was } \\
\text { responsible for late-night } \\
\text { programming: poetry } \\
\text { around midnight, when } \\
\text { only the pines in the } \\
\text { Black Forest were still } \\
\text { listening. } \\
\text { (Grass, 2002/2004, p. 16) }\end{array}$ & & $\begin{array}{l}\text { stod som } \\
\text { kulturredaktør for det } \\
\text { sene aftenprogram i } \\
\text { Südwestfunk: lyrik hen } \\
\text { ad midnat, når } \\
\text { grantræerne } \quad \text { i } \\
\text { Schwarzwald var de } \\
\text { eneste lyttere. } \\
\text { (Grass, 2002/2002, p. } \\
\text { 18) }\end{array}$ & \\
\hline $\begin{array}{l}\text { Da ich } \\
\text { Schulfreundin nutters } \\
\text { dauerhaft auf der Tasche } \\
\text { liegen wollte, habe ich in } \\
\text { einem an sich netten } \\
\text { Brief, gleich nach der } \\
\text { Schlußfloskel »Dein Dir } \\
\text { unbekannter Sohn } \\
\text { schön leserlich meine } \\
\text { Kontonummer zur } \\
\text { Kenntnis gebracht, } \\
\text { (Grass, 2007, p. 20) }\end{array}$ & $\begin{array}{l}\text { Since I didn't want to be } \\
\text { hitting up Mother's } \\
\text { girlfriend for money all } \\
\text { the time, I fired off a } \\
\text { rather nice letter, if I do } \\
\text { say so myself, and after } \\
\text { the closing flourish, } \\
\text { "Your unknown son," I } \\
\text { made sure to include my } \\
\text { bank account number, in } \\
\text { my most legible } \\
\text { handwriting. (Grass, } \\
2002 / 2004, \text { p. 16) }\end{array}$ & $=$ & $\begin{array}{l}\text { Da jeg ikke ville ligge } \\
\text { mors skolekammerat til } \\
\text { byrde i al evighed, } \\
\text { oplyste jeg i et i og for } \\
\text { sig meget flinkt brev, } \\
\text { lige efter } \\
\text { afslutningsklicheen } \\
\text { "din dig ubekendte } \\
\text { søn", smukt og } \\
\text { letlæseligt mant mit } \\
\text { kontonummer. (Grass, } \\
\text { 2002/2002, p. 19) }\end{array}$ & $=$ \\
\hline $\begin{array}{l}\text { Da waren die drei } \\
\text { Helden, die mir jetzt } \\
\text { wichtig sein müssen, } \\
\text { besser dran. Jedenfalls } \\
\text { hat Mutter selbst nicht } \\
\text { gewußt, wer sie } \\
\text { geschwängert hatte, als } \\
\text { sie mit ihren Eltern am } \\
\text { Vormittag des } 30 \text {. Januar } \\
\text { fünfundvierzig vom Kai } \\
\text { Gotenhafen-Oxhöft weg } \\
\text { als } \\
\text { Siebentausendsoundsovie } \\
\text { lte eingeschifft wurde. } \\
\text { Derjenige, nach dem das } \\
\text { Schiff getauft worden } \\
\text { war, konnte einen } \\
\text { Kaufmann, Hermann }\end{array}$ & $\begin{array}{l}\text { In that respect the three } \\
\text { heroes I've been } \\
\text { instructed to focus on } \\
\text { were better off. It's clear, } \\
\text { at any rate, that Mother } \\
\text { really had no idea by } \\
\text { whom she was pregnant } \\
\text { when she set out on that } \\
\text { morning of } 30 \text { January } \\
\text { 1945 with her parents, } \\
\text { leaving the Gotenhafen- } \\
\text { Oxhöft pier as passenger } \\
\text { number seven thousand } \\
\text { such-and-such. The man } \\
\text { for whom the ship had } \\
\text { been named could } \\
\text { identify a businessman, } \\
\text { Hermann Gustloff, as his }\end{array}$ & - & $\begin{array}{l}\text { Så havde de tre helte, } \\
\text { som nu skal være } \\
\text { vigtige for mig, det } \\
\text { bedre. I hvert fald har } \\
\text { mor ikke selv vidst, } \\
\text { hvem der havde gjort } \\
\text { hende gravid, da hun } \\
\text { sammen med sine } \\
\text { forældre om } \\
\text { formiddagen den } 30 . \\
\text { januar femogfyrre blev } \\
\text { indskibet som nummer } \\
\text { syvtusindsåogså- } \\
\text { mange fra kajen i } \\
\text { Gotenhafen-Oxhöft. } \\
\text { Han, som skibet var } \\
\text { opkaldt efter, kunne }\end{array}$ & + \\
\hline
\end{tabular}




\begin{tabular}{|c|c|c|c|c|}
\hline 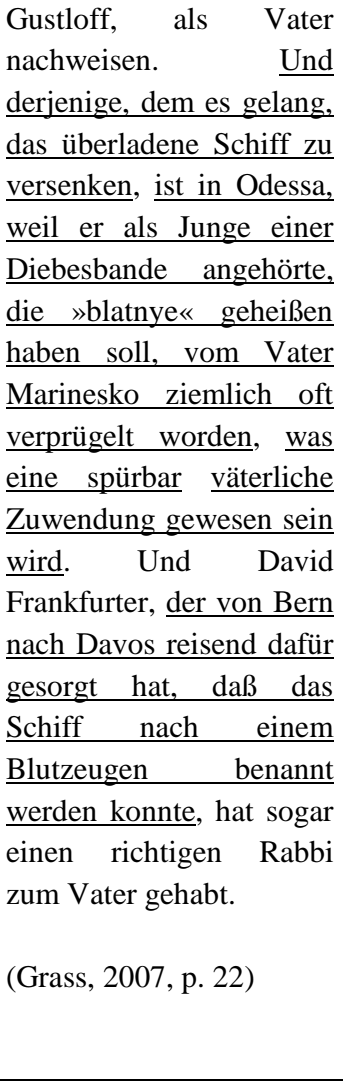 & $\begin{array}{l}\text { father. And as a boy in } \\
\text { Odessa, the man who } \\
\text { succeeded in sinking the } \\
\text { overcrowded ship had } \\
\text { received fairly regular } \\
\text { beatings from Papa } \\
\text { Marinesko -tangible } \\
\text { proof of paternal } \\
\text { solicitude- for belonging } \\
\text { to a band of thieves, } \\
\text { reportedly known as } \\
\text { blatnye. And David } \\
\text { Frankfurter, } \\
\text { travelled from Berne to } \\
\text { Davos to set in motion } \\
\text { the process by which the } \\
\text { ship came to be named } \\
\text { for a martyr, had an } \\
\text { honest-to-goodness rabbi } \\
\text { as his father. } \\
\text { (Grass, 2002/2004, p. } \\
\text { 18) }\end{array}$ & & 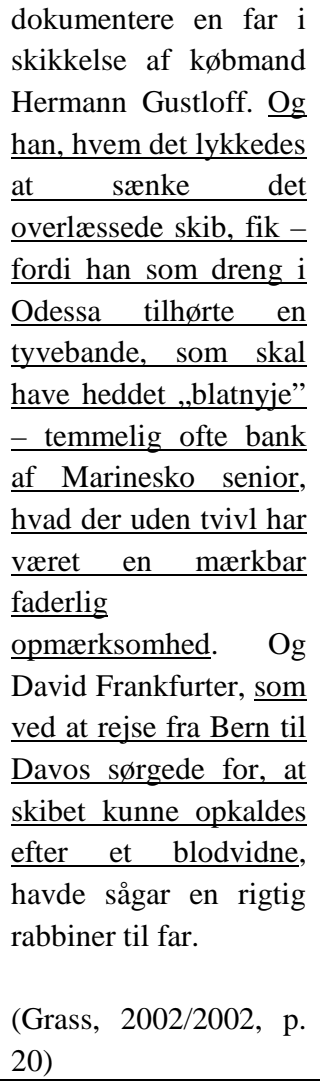 & \\
\hline $\begin{array}{l}\text { Und was hat den Nazis, } \\
\text { frage ich mich, ein } \\
\text { Blutzeuge } \\
\text { eingebracht? } \mathrm{Na} \text { schön, } \\
\text { ein Schiff wurde auf } \\
\text { seinen Namen getauft. } \\
\text { (Grass, 2007:31) }\end{array}$ & $\begin{array}{l}\text { And what good did } \\
\text { another martyr do the } \\
\text { Nazis, I wonder. Well, } \\
\text { all right, they named a } \\
\text { ship after him. } \\
\text { (Grass, 2004:28) }\end{array}$ & $=$ & $\begin{array}{l}\text { Og hvad fik nazisterne, } \\
\text { spørger jeg mig selv, } \\
\text { ud af et blodvidne } \\
\text { mere? Bevares, der } \\
\text { blev opkaldt et skib } \\
\text { efter ham. } \\
\text { (Grass, 2002:28) }\end{array}$ & $=$ \\
\hline $\begin{array}{l}\text { »Stimmt«, habe ich } \\
\text { gesagt, »aus mir ist nix } \\
\text { Tolles geworden, wird } \\
\text { auch nix mehr. Doch wie } \\
\text { du siehst, Mutter, } \\
\text { entwickle ich mich - }\end{array}$ & $\begin{array}{l}\text { "Right", I told her, "I } \\
\text { haven't amounted to } \\
\text { much, and it's too late } \\
\text { now. But as you see, } \\
\text { Mother, I'm developing } \\
\text {-if you can call it that- }\end{array}$ & $=$ & $\begin{array}{l}\text { „Sandt nok,” sagde jeg, } \\
\text {,jeg er ikke blevet til } \\
\text { noget fantastisk, det er } \\
\text { også for sent nu. Men } \\
\text { som du ser, mor, } \\
\text { udvikler jeg mig - hvis }\end{array}$ & $=$ \\
\hline
\end{tabular}




\begin{tabular}{|c|c|c|c|c|}
\hline $\begin{array}{l}\text { wenn man das } \\
\text { Entwicklung nennen darf } \\
\text { - zum Kettenraucher.« } \\
\text { (Grass, 2007:45) }\end{array}$ & $\begin{array}{l}\text { into a chain-smoker." } \\
\text { (Grass, 2004:44) }\end{array}$ & & $\begin{array}{l}\text { man tør kalde det en } \\
\text { udvikling }- \\
\text { kæderyger. } \\
\text { (Grass, 2002:40) }\end{array}$ & \\
\hline $\begin{array}{l}\text { Ziemlich sicher bin ich } \\
\text { dennoch, daß sich mein } \\
\text { Schweriner Webmaster } \\
\text { rechtzeitig ein Exemplar } \\
\text { hat kommen lassen, denn } \\
\text { seine Internet-Seiten } \\
\text { waren gespickt mit } \\
\text { Grimm-Zitaten und } \\
\text { polemischen Antworten } \\
\text { auf das -zugegeben- } \\
\text { langatmige Plädoyer des } \\
\text { Verteidigers Curti. } \\
\text { (Grass, 2007:46) }\end{array}$ & $\begin{array}{l}\text { I am fairly certain, } \\
\text { however, that my } \\
\text { Schwerin Webmaster } \\
\text { ordered a copy while it } \\
\text { was still available, for his } \\
\text { internet site bristles with } \\
\text { Grimm quotations and } \\
\text { polemical retorts to the } \\
\text { admittedly long-winded } \\
\text { defense offered by Curti. } \\
\text { (Grass, 2004:45) }\end{array}$ & - & $\begin{array}{l}\text { Jeg er ikke desto } \\
\text { mindre } \\
\text { sikker på, at min } \\
\text { webmaster i Schwerin } \\
\text { har sørget for at få fat i } \\
\text { et eksemplar, mens tid } \\
\text { var, for hans } \\
\text { internetsider var } \\
\text { spækket med Grimm- } \\
\text { citater og polemiske } \\
\text { svar på forsvarer Curtis } \\
\text { - indrømmet - } \\
\text { langstrakte indlæg. } \\
\text { (Grass, 2002:41) }\end{array}$ & - \\
\hline $\begin{array}{l}\text { Konnte das nicht mehr } \\
\text { mitanhören, wenn sie mir, } \\
\text { meistens sonntags, ihre } \\
\text { Gustloff-Geschichten zu } \\
\text { klopsen und } \\
\text { Stampfkartoffeln } \\
\text { auftischte (1): »Kam alles } \\
\text { ins Rutschen. Kann man } \\
\text { nich vergässen, sowas. } \\
\text { Das heert nie auf. Da } \\
\text { träum ech nich nur von, } \\
\text { wie, als Schluß war, ain } \\
\text { ainziger Schrei ieberm } \\
\text { Wasser losjing. Ond all } \\
\text { die Kinderchen zwischen } \\
\text { die Eisschollen...«(2) } \\
\text { Manchmal hat Mutter, } \\
\text { wenn sie nach dem } \\
\text { Sonntagsessen mit ihrem } \\
\text { Pott Kaffee am } \\
\text { Küchentisch saß, nur } \\
\text { »War aijentlich ain }\end{array}$ & $\begin{array}{l}\text { Just couldn't take it any } \\
\text { more when, usually at } \\
\text { Sunday dinner, she } \\
\text { would dish up her } \\
\text { histories of the Gustloff } \\
\text { along with the dumplings } \\
\text { and mashed potatoes (1): } \\
\text { "Everything started to } \\
\text { slither. A thing like that } \\
\text { you never forget. It never } \\
\text { leaves you. It's not just } \\
\text { in my dreams, that cry } \\
\text { that spread over the } \\
\text { water at the end there. } \\
\text { And all them little } \\
\text { children among the ice } \\
\text { floes..." (2) } \\
\text { Sometimes } \\
\text { Mother sat at the kitchen } \\
\text { table after Sunday dinner } \\
\text { with her mug of coffee, } \\
\text { she would say only, }\end{array}$ & - & $\begin{array}{l}\text { Jeg kunne ikke længer } \\
\text { holde ud at høre på det, } \\
\text { når hun, mest om } \\
\text { søndagen, serverede } \\
\text { sine Gustloff-historier } \\
\text { til frikadeller og } \\
\text { kartoffelmos (1). „Det } \\
\text { begyndte alt sammen } \\
\text { at rutsche. Sådan noget } \\
\text { ka' man ikke glemme. } \\
\text { Det holder aldrig op. } \\
\text { Det er ikke kun mig, } \\
\text { der drømmer om det, } \\
\text { hvordan ét eneste skrig } \\
\text { brød løs over vandet, } \\
\text { da det var slut. Og så } \\
\text { alle de små børn } \\
\text { mellem isflagerne...” } \\
\text { (2) } \\
\text { Undertiden sagde } \\
\text { mor, når hun efter } \\
\text { søndagsmiddagen sad }\end{array}$ & - \\
\hline
\end{tabular}




\begin{tabular}{|c|c|c|c|c|}
\hline $\begin{array}{l}\text { scheenes Schiff« (2) } \\
\text { gesagt, danach kein Wort } \\
\text { mehr. Aber ihr } \\
\text { Binnichtzuhauseblick } \\
\text { sagte genug. } \\
\text { (Grass, 2007:57) }\end{array}$ & $\begin{array}{l}\text { "That sure was one } \\
\text { beautiful ship," (2) and } \\
\text { then not another word. } \\
\text { But her I'm-not-home } \\
\text { look spoke volumes. } \\
\text { (Grass, 2004:57) }\end{array}$ & & $\begin{array}{l}\text { ved køkkenbordet med } \\
\text { sin kaffekop, bare „Det } \\
\text { var i grunden et smukt } \\
\text { skib” (2), og så ikke et } \\
\text { ord mere. Men hendes } \\
\text { jegerikkehjemmeblik } \\
\text { sagde tilstrækkeligt. } \\
\text { (Grass, 2002:50) }\end{array}$ & \\
\hline $\begin{array}{l}\text { Auf unserer globalen } \\
\text { Spielwiese, } \\
\text { gepriesenen dem } \\
\text { letztmöglicher } \\
\text { Kommunikation, hieß das } \\
\text { sowjetische U-Boot S13 } \\
\text { im Wortlaut der mir } \\
\text { familiär nahen Website } \\
\text { kategorisch: } \\
\text { Mordboot«. } \\
\text { (Grass, 2007:133) }\end{array}$ & $\begin{array}{l}\text { On our global } \\
\text { playground, the vaunted } \\
\text { ultimate venue for } \\
\text { communication, the } \\
\text { Soviet U-boat } S-13 \text { was } \\
\text { labeled categorically "the } \\
\text { murder vessel," this on } \\
\text { the Web site to which I } \\
\text { had a familial } \\
\text { connection. (Grass, } \\
2004: 142)\end{array}$ & - & $\begin{array}{l}\text { På vores } \quad \text { globale } \\
\underline{\text { legeplads, den sidst }} \\
\underline{\text { mulige }} \\
\text { kommunikations } \\
\underline{\text { lovpriste sted, hed den }} \\
\text { sovjetiske ubåd S13 i } \\
\text { den mig familiært } \\
\text { nærstående } \\
\text { hjemmesides } \\
\text { sprogbrug kategorisk: } \\
\text { „Mordbåden”. (Grass, } \\
\text { 2002:118) }\end{array}$ & - \\
\hline $\begin{array}{l}\text { Mein Sohn verstand es, } \\
\text { Bilder und Bildchen, } \\
\text { Tabellen und Dokumente } \\
\text { geschickt zu plazieren. So } \\
\text { konnte auf seiner Website } \\
\text { nicht nur die Vorder-, } \\
\text { auch die Rückseite des } \\
\text { überragenden Granits, } \\
\text { aufgerichtet am Südufer } \\
\text { des Schweriner Sees, } \\
\text { besichtigt werden. Er } \\
\text { hatte sich Mühe gegeben } \\
\text { und neben der } \\
\text { fotografierten } \\
\text { Gesamtansicht des Steins } \\
\text { eine Vergrößerung der } \\
\text { sonst schwer lesbaren } \\
\text { Inschrift zur Anschauung } \\
\text { gebracht, die auf der } \\
\text { Hinterseite gemeißelt } \\
\text { stand. Übereinander drei } \\
\text { Zeilen: »Gelebt für die }\end{array}$ & $\begin{array}{l}\text { My son was clever at } \\
\text { positioning pictures and } \\
\text { icons, tables and } \\
\text { documents. Thus one } \\
\text { could view on his Web } \\
\text { site not only the front but } \\
\text { also the back of the } \\
\text { mighty granite boulder } \\
\text { erected on the southern } \\
\text { shore of Lake Schwerin. } \\
\text { He had gone to the } \\
\text { trouble of providing an } \\
\text { enlargement of the } \\
\text { chiseled inscription that } \\
\text { was barely legible on the } \\
\text { photograph showing the } \\
\text { entire stone from the } \\
\text { rear. Three lines, one } \\
\text { above the other: LIVED } \\
\text { FOR THE MOVEMENT } \\
\text { - MURDERED BY A } \\
\text { JEW - DIED FOR }\end{array}$ & $=$ & $\begin{array}{l}\text { Min søn forstod sig på } \\
\text { at anbringe store og } \\
\text { små billeder, tabeller } \\
\text { og dokumenter på de } \\
\text { strategisk rigtige } \\
\text { steder. Altså kunne } \\
\text { man på hans } \\
\text { hjemmeside ikke alene } \\
\text { besigtige for-, men } \\
\text { også bagsiden af den } \\
\text { højtopragende } \\
\text { granitsten, som var } \\
\text { rejst på sydbredden af } \\
\text { Schweriner See. Han } \\
\text { havde lagt sig i selen } \\
\text { og ved siden af det } \\
\text { fotograferede totalblik } \\
\text { på stenen også sørget } \\
\text { for at udstille en } \\
\text { forstørrelse af den } \\
\text { ellers svært læselige } \\
\text { indskrift, som stod }\end{array}$ & $=$ \\
\hline
\end{tabular}




\begin{tabular}{|c|c|c|}
\hline $\begin{array}{lr}\text { Bewegung } & - \\
\text { Gemeuchelt vom Juden } \\
-\quad \text { Gestorben für } \\
\text { Deutschland } \ll . \\
\\
\text { (Grass, 2007:171) }\end{array}$ & $\begin{array}{l}\text { GERMANY. } \\
\text { (Grass, 2004:183). }\end{array}$ & $\begin{array}{l}\text { indhugget på bagsiden. } \\
\text { Tre linjer under } \\
\text { hinanden: „Levede for } \\
\text { Bevægelsen } \\
\text { Snigmyrdedes af Jøden } \\
\text { - Døde for Tyskland”. } \\
\text { (Grass, 2002:150) }\end{array}$ \\
\hline
\end{tabular}

Table 9: Results of the analysis (German, Catalan, and Spanish)

\begin{tabular}{|c|c|c|c|c|}
\hline ST & Catalan & & Spanish & \\
\hline 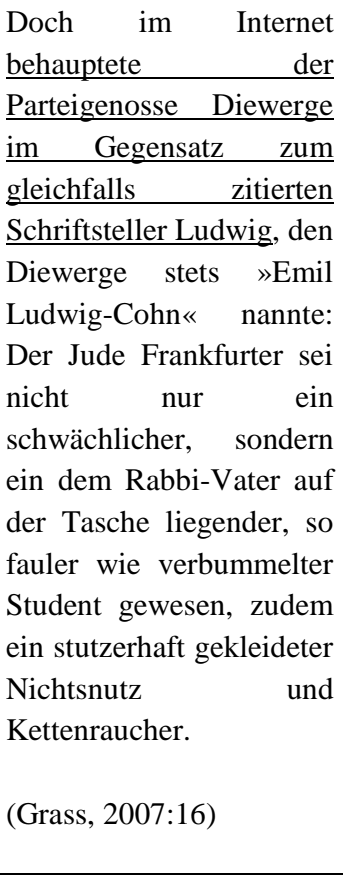 & $\begin{array}{l}\text { Però el camarada } \\
\text { Diewerge afirmava a } \\
\text { Internet, contradint } \\
\text { l'igualment r citat } \\
\text { escriptor Ludwig, a qui } \\
\text { Diewerge anomenava } \\
\text { «Emil Ludwig-Cohn», } \\
\text { que el jueu Franfurter no } \\
\text { tan sols havia estat un } \\
\text { estudiant malaltís, sinó } \\
\text { que també vivia a les } \\
\text { costelles del pare rabí, de } \\
\text { tan gandul i dropo com } \\
\text { era, i que a més era un } \\
\text { gallòfol i un fumador } \\
\text { empedreit disfressat de } \\
\text { gomós. } \\
\text { (Grass, 2003a:14) }\end{array}$ & $=$ & $\begin{array}{l}\text { Sin embargo, en } \\
\text { Internet, el compañero } \\
\text { Diewerge, a diferencia } \\
\text { del igualmente citado } \\
\text { autor Ludwig al que } \\
\text { Diewerge llamaba } \\
\text { siempre_Emil } \\
\text { Ludwig-Cohn», } \\
\text { afirmaba que el judío } \\
\text { Frankfurter no sólo era } \\
\text { enfermizo, sino } \\
\text { también alguien que } \\
\text { vivía a costa de su } \\
\text { padre rabino, un } \\
\text { estudiante tan vago } \\
\text { como eterno, y además } \\
\text { un inútil que se vestía } \\
\text { como un dandi y era } \\
\text { fumador empedernido. } \\
\text { (Grass, 2003b:19) }\end{array}$ & - \\
\hline $\begin{array}{l}\text { Man soll nicht } \\
\text { vergleichen. Doch was } \\
\text { das Pekuniäre betraf, ging } \\
\text { es mir bald wie David } \\
\text { Frankfurter in Bern, dem } \\
\text { der ferne Vater monatlich } \\
\text { ein Sümmchen aufs } \\
\text { Schweizer Konto legte. } \\
\text { Mutters Cousin -hab ihn }\end{array}$ & $\begin{array}{l}\text { No s'han de fer } \\
\text { comparacions. Però, pel } \\
\text { que fa a la pecúnia, aviat } \\
\text { les coses em van anar } \\
\text { com a en David } \\
\text { Frankfurter a Berna, a } \\
\text { qui el pare llunyà } \\
\text { ingressava cada mes una } \\
\text { petita suma en un compte }\end{array}$ & - & $\begin{array}{l}\text { No hay que comparar. } \\
\text { Sin embargo, en lo que } \\
\text { se refiere a lo } \\
\text { pecuniario, pronto me } \\
\text { fue como a David } \\
\text { Franfurter en Berna, a } \\
\text { quien su lejano padre } \\
\text { ingresaba todos los } \\
\text { meses en su cuenta }\end{array}$ & 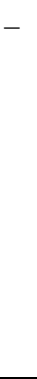 \\
\hline
\end{tabular}




\begin{tabular}{|c|c|c|c|c|}
\hline $\begin{array}{l}\text { selig- hieß Harry } \\
\text { Liebenau, war Sohn des } \\
\text { Tischlermeisters in der } \\
\text { einstigen Elsenstraße, } \\
\text { lebte seit Ende der } \\
\text { fünfziger Jahre in Baden- } \\
\text { Baden und machte als } \\
\text { Kulturredakteur für den } \\
\text { Südwestfunk } \\
\begin{array}{l}\text { Nachtprogramm: Lyrik } \\
\text { gegen Mitternacht, }\end{array} \\
\text { nur nenn } \\
\text { Schwartzwaldtannen } \\
\underline{\text { zuhörten. }} \\
\text { (Grass, 2007:20) }\end{array}$ & $\begin{array}{l}\text { suís. El cosí de la mare - } \\
\text { que en pau descansi- es } \\
\text { deia Harry Liebenau, era } \\
\text { fill del mestrer fuster de } \\
\text { l'antic carrer Elsen, va } \\
\text { viure des de la darreria } \\
\text { dels anys cinquantes a } \\
\text { Baden-Baden i feia el } \\
\text { programa nocturn de la } \\
\text { Ràdio Sud-est com a } \\
\text { redactor cultural, Lírica a } \\
\text { mitjanit, si és que } \\
\text { l'escoltaven ni que fossin } \\
\text { els avets de la Selva } \\
\text { Negra. } \\
\text { (Grass, 2003a:18) }\end{array}$ & & 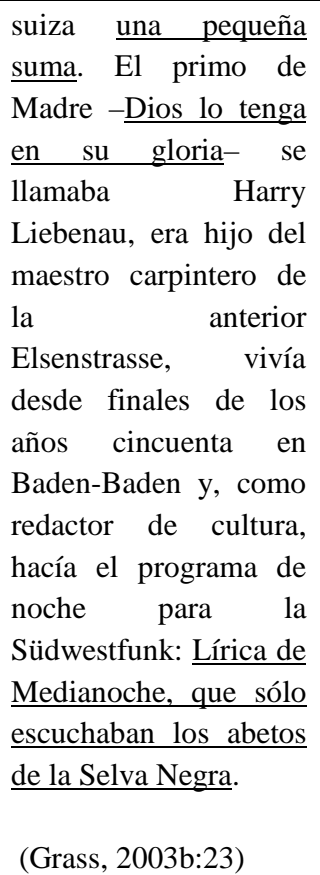 & \\
\hline $\begin{array}{l}\text { Da ich } \\
\text { Schulfreundin nutters } \\
\text { dauerhaft auf der Tasche } \\
\text { liegen wollte, habe ich in } \\
\text { einem an sich netten } \\
\text { Brief, gleich nach der } \\
\text { Schlußfloskel } \text { Dein Dir } \\
\text { unbekannter Sohn } \\
\text { schön leserlich meine } \\
\text { Kontonummer zur } \\
\text { Kenntnis gebracht. } \\
\text { (Grass, 2007:20) }\end{array}$ & $\begin{array}{l}\text { Com que jo no volia } \\
\text { viure permanentment a } \\
\text { càrrec de l'amiga } \\
\text { d'escola de la mare, vaig } \\
\text { fer saber a aquell bon } \\
\text { home el meu número de } \\
\text { compte en una carta molt } \\
\underline{\text { llegidora que acabava }} \\
\text { amb la fórmula de } \\
\text { cortesia «el teu fill } \\
\text { desconegut». } \\
\text { (Grass, 2003a:18) }\end{array}$ & - & $\begin{array}{l}\text { Como no quería vivir } \\
\text { permanentemente a } \\
\text { costa de la amiga del } \\
\text { colegio de Madre, en } \\
\text { una carta en el fondo } \\
\text { amable, } \\
\text { inmediatamente } \\
\text { después de la fórmula } \\
\text { final de cortesía «Tu } \\
\text { hijo al que no } \\
\text { conoces», le había } \\
\text { dado a conocer, muy } \\
\text { legiblemente, el } \\
\text { número de mi cuenta. } \\
\text { (Grass, 2003b:24) }\end{array}$ & $=$ \\
\hline $\begin{array}{l}\text { Da waren die drei } \\
\text { Helden, die mir jetzt } \\
\text { wichtig sein müssen, } \\
\text { besser dran. Jedenfalls } \\
\text { hat Mutter selbst nicht }\end{array}$ & $\begin{array}{l}\text { Posats a fer, eren millor } \\
\text { els tres herois, que ara } \\
\text { seran importants per a } \\
\text { mi. En tot cas, la mare no } \\
\text { sabia qui l'havia deixada }\end{array}$ & - & $\begin{array}{l}\text { En eso tuvieron más } \\
\text { suerte los tres héroes } \\
\text { que tendrían que serme } \\
\text { ahora importantes. En } \\
\text { cualquier caso, Madre }\end{array}$ & - \\
\hline
\end{tabular}




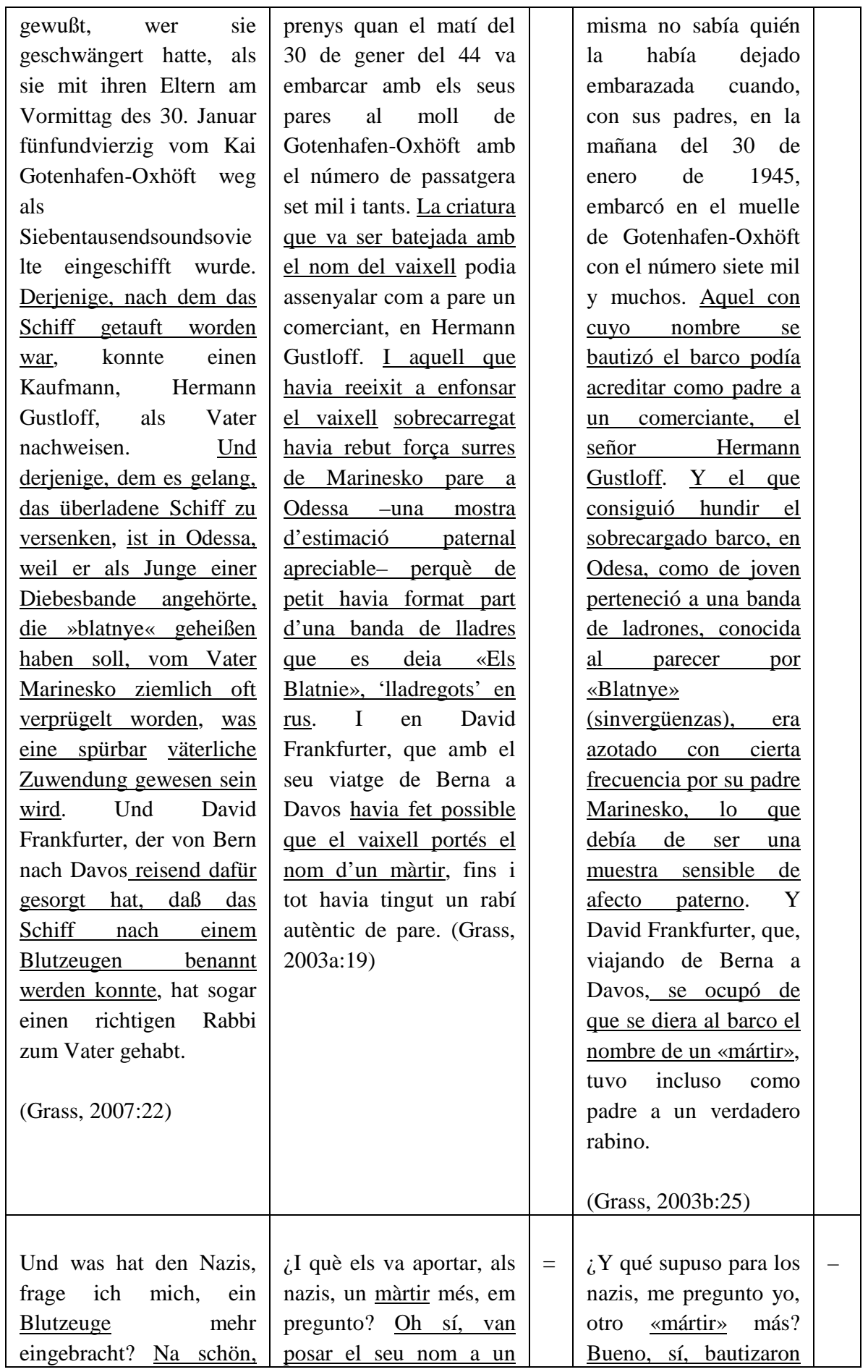




\begin{tabular}{|c|c|c|c|c|}
\hline $\begin{array}{l}\text { ein Schiff wurde auf } \\
\text { seinen Namen getauft. } \\
\text { (Grass, 2007:31) }\end{array}$ & $\begin{array}{l}\text { vaixell. } \\
\text { (Grass, 2003a:28) }\end{array}$ & & $\begin{array}{l}\text { un barco con su } \\
\underline{\text { nombre. }} \\
\text { (Grass, 2003b:35) }\end{array}$ & \\
\hline $\begin{array}{l}\text { »Stimmt«, habe ich } \\
\text { gesagt, »aus mir ist nix } \\
\text { Tolles geworden, wird } \\
\text { auch nix mehr. Doch wie } \\
\text { du siehst, Mutter, } \\
\text { entwickle ich mich - } \\
\text { wenn man das } \\
\text { Entwicklung nennen darf } \\
\text { - } \underline{\text { zum Kettenraucher." }} \\
\text { (Grass, 2007:45) }\end{array}$ & $\begin{array}{l}\text {-És veritat -vaig dir jo-, } \\
\text { jo no he sigut res de } \\
\text { l'altre món i ja no ho } \\
\text { seré. Però, com pots } \\
\text { veure, mare, he } \\
\text { progressat, si es pot dir } \\
\text { progrés això de fumar } \\
\text { com un carreter. } \\
\text { (Grass, 2003a:40) }\end{array}$ & + & 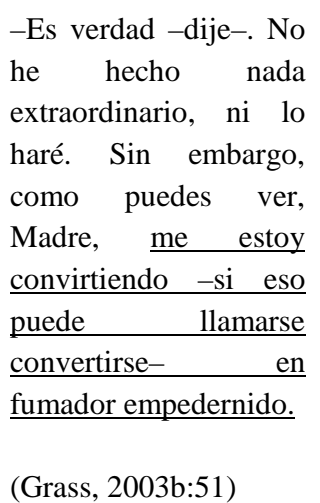 & - \\
\hline $\begin{array}{l}\text { Ziemlich sicher bin ich } \\
\text { dennoch, daß sich mein } \\
\text { Schweriner Webmaster } \\
\text { rechtzeitig ein Exemplar } \\
\text { hat kommen lassen, denn } \\
\text { seine Internet-Seiten } \\
\text { waren gespickt mit } \\
\text { Grimm-Zitaten and } \\
\text { polemischen Antworten } \\
\text { auf das -zugegeben- } \\
\text { langatmige Plädoyer des } \\
\text { Verteidigers } \\
\text { (Grass, 2007:46) }\end{array}$ & $\begin{array}{l}\text { Tanmateix estic força } \\
\begin{array}{l}\text { convençut que el meu } \\
\text { administrador de webs de }\end{array} \\
\underline{\text { Schwerin en va }} \\
\text { encarregar un exemplar a } \\
\text { temps, perquè les seves } \\
\text { pàgines d'Internet } \\
\text { estaven farcides de } \\
\text { citacions de Grimm i de } \\
\text { respostes polèmiques a } \\
\text { l'informe -ho admeto- } \\
\text { prolix del defensor Curti. } \\
\text { (Grass, 2003a:41) }\end{array}$ & $=$ & 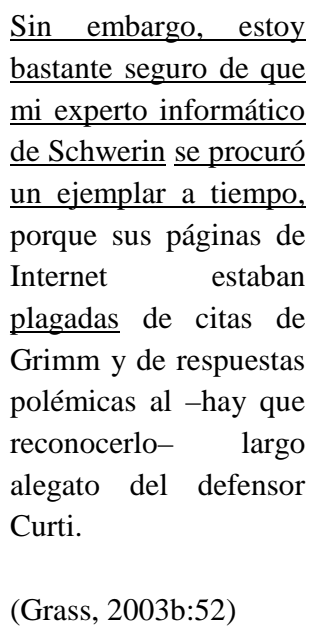 & - \\
\hline $\begin{array}{l}\text { Konnte das nicht mehr } \\
\text { mitanhören, wenn sie mir, } \\
\text { meistens sonntags, ihre } \\
\text { Gustloff-Geschichten zu } \\
\text { klopsen und } \\
\text { Stampfkartoffeln } \\
\text { auftischte (1): »Kam alles } \\
\text { ins Rutschen. Kann man } \\
\text { nich vergässen, sowas. } \\
\text { Das heert nie auf. Da }\end{array}$ & $\begin{array}{l}\text { Ja no la podia escoltar } \\
\text { més quan, sobretot els } \\
\text { diumenges, mentre em } \\
\text { servia mandonguilles i } \\
\text { puré de patates, } \\
\text { m'explicava les seves } \\
\text { històries del Gustloff (1): } \\
\text {-Tot relliscava. Són } \\
\text { coses que te'n recordes. }\end{array}$ & - & $\begin{array}{l}\text { No podía oírla ya } \\
\text { cuando, generalmente } \\
\text { los domingos, me } \\
\text { servía, con puré de } \\
\text { patatas y albóndigas, } \\
\text { sus historias del } \\
\text { Gustloff (1): } \\
\text {-Tó empezó a } \\
\text { resbalarse. No se pué }\end{array}$ & - \\
\hline
\end{tabular}




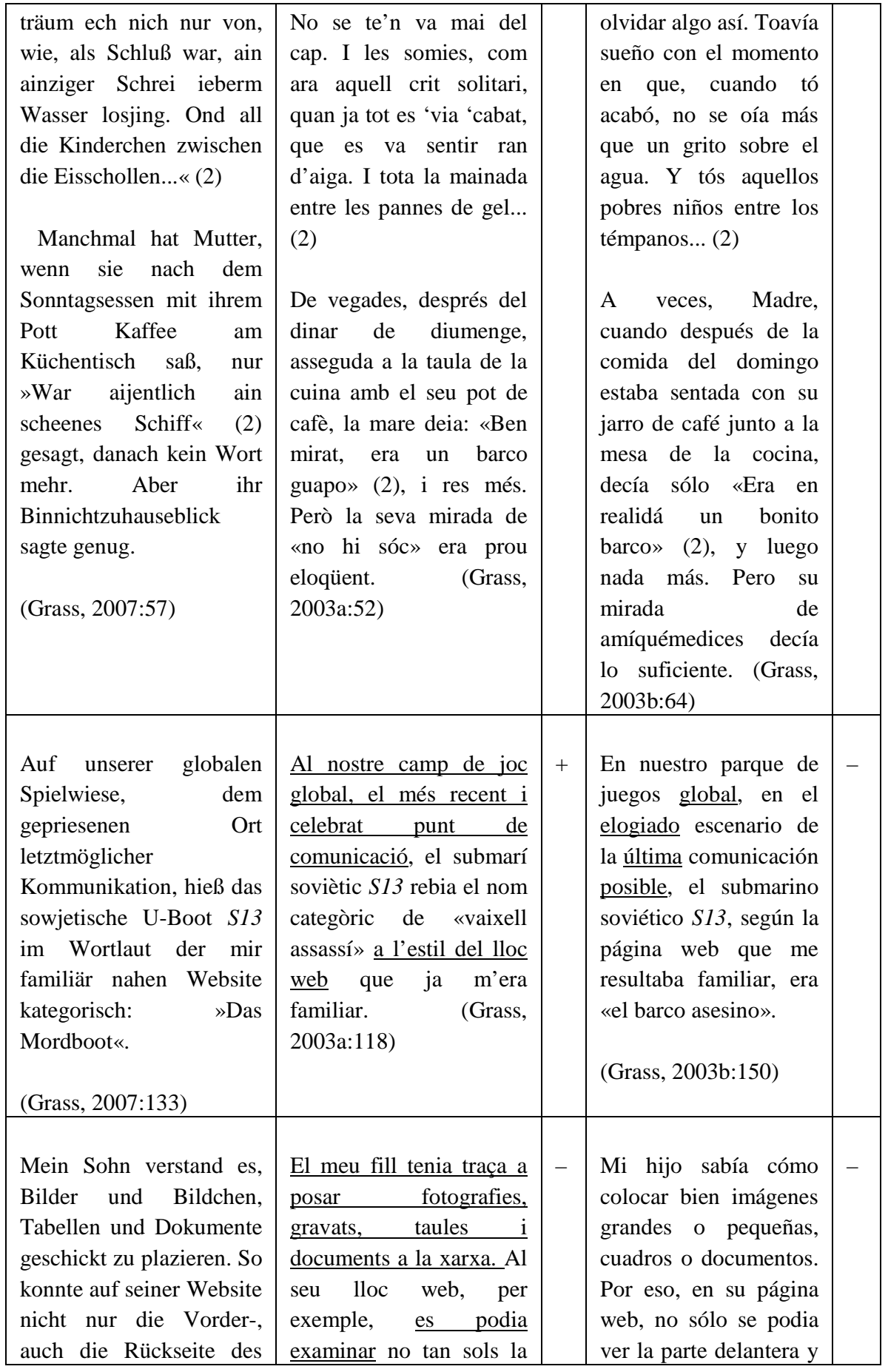




\begin{tabular}{|c|c|c|}
\hline $\begin{array}{l}\text { überragenden Granits, } \\
\text { aufgerichtet am Südufer } \\
\text { des Schweriner Sees, } \\
\text { besichtigt werden. Er } \\
\text { hatte sich Mühe gegeben } \\
\text { und neben der } \\
\text { fotografierten } \\
\text { Gesamtansicht des Steins } \\
\text { eine Vergrößerung der } \\
\text { sonst schwer lesbaren } \\
\text { Inschrift zur Anschauung } \\
\text { gebracht, die auf der } \\
\text { Hinterseite gemeißelt } \\
\text { stand. Übereinander drei } \\
\text { Zeilen: »Gelebt für die } \\
\text { Bewegung } \\
\text { Gemeuchelt vom Juden } \\
\text { Gestorben für } \\
\text { Deutschland «. } \\
\text { (Grass, 2007:171) }\end{array}$ & $\begin{array}{l}\text { part de davant del granit } \\
\text { erigit a la ribera sud del } \\
\text { llac de Schwerin, sinó } \\
\text { també la del darrere. S'hi } \\
\text { havia escarrassat i, al } \\
\text { costat de la vista de } \\
\text { conjunt de la pedra, } \\
\text { exhibia una ampliació de } \\
\text { la inscripció altrament } \\
\text { difícil de llegir, cisellada } \\
\text { a la part posterior. Tres } \\
\text { línies l'una damunt de } \\
\text { l'altra: «Viscut per al } \\
\text { moviment - assassinat } \\
\text { pels jueus - mort per } \\
\text { Alemanya.» } \\
\text { (Grass, 2003a:150). }\end{array}$ & $\begin{array}{l}\text { trasera del descollante } \\
\text { bloque de granito, } \\
\text { levantado en la orilla } \\
\text { meridional del lago de } \\
\text { Schwerin. Se había } \\
\text { molestado y, junto a la } \\
\text { vista fotográfica } \\
\text { general de la piedra, } \\
\text { había mostrado una } \\
\text { ampliación de la } \\
\text { inscripción, } \\
\text { normalmente difícil de } \\
\text { leer, que había grabada } \\
\text { en la parte trasera. Tres } \\
\text { líneas, una encima de } \\
\text { otra: «Vivió por el } \\
\text { Movimiento - Fue } \\
\text { vilmente asesinado por } \\
\text { los judíos - Murió por } \\
\text { Alemania». } \\
\text { (Grass, 2003b:193) }\end{array}$ \\
\hline
\end{tabular}




\section{References}

\section{Primary sources}

Grass, G. (2007). Im Krebsgang (3rd ed.). München: Deutscher Taschenbuch Verlag.

Grass, G. (2002). I krebsegang. (2nd ed.). P. Øhrgaard (Translated into Danish. German original Im Krebsgang, 2002). Haslev: Gyldendal.

Grass, G. (2003a). Com els crancs. J. Fontcuberta (Translated into Catalan. German original Im Krebsgang, 2002). Barcelona: Edicions 62.

Grass, G. (2003b). A paso de cangrejo. M. Sáenz (Translated into Spanish. German original Im Krebsgang, 2002). Madrid: Alfaguara.

Grass, G. (2004). Crabwalk. K. Winston (Translated into English. German original Im Krebsgang, 2002). London: Faber and Faber.

\section{Secondary sources}

Anscombre, J. C., \& Ducrot, O. (1983). L’Argumentation dans la langue. Brussels: Mardaga.

Argaman, O. (2009). Linguistic markers and emotional intensity. Journal of Psycholinguistic Research, 39(2), 89-99. doi: 10.1007/s10936-009-9127-1

Bal, M. (1987). Teoría de la narrativa. (2nd ed.). J. Franco (Translated into Spanish. Dutch original De theorie van vertellen en verhalen, 1980). Madrid: Cátedra.

Behler, E. (1990). Irony and the discourse of modernity. Seattle: University of Washington Press.

Catalan dictionary: English-Catalan, Catalan-English (1994). London: Routledge.

Collins Spanish Dictionary (7th ed.). (2003). Glasgow: HarperCollins.

Coromines i Calders, D. (2009). Les divergències d'intensitat en la traducció d'emocions i actituds: L'enuig i la ironia a les versions catalana i castellana de l'obra Unkenrufe. In V. Alsina, G. Andújar \& M. Tricás (Eds.), La representación del discurso individual en traducción (pp. 86-104). Frankfurt: Peter Lang.

Coromines i Calders, D. (2010). Intensification, reduction or preservation of irony? Günter Grass's Im Krebsgang and its translation into english. In C. ValeroGarcés (Ed.), Dimensions of humor. Explorations in Linguistics, Literature, Cultural Studies and Translation (pp. 145-170). València: Universitat de València.

Coseriu, E. (1986). Introducción a la lingüística. (2nd ed.). Madrid: Gredos.

Dansk-Engelsk ordbog (9th ed.). (1992). Copenhagen: Gyldendal.

Das digitale Wörterbuch der Deutschen Sprache. Web site: http://www.dwds.de/textbasis.

Den danske ordbog. Web site: http://ordnet.dk/ddo 
Deutsches Universalwörterbuch (5th ed.). (2003). Mannheim: Dudenverlag.

Diccionari de la llengua catalana (2nd ed.). (2007). Barcelona: Institut d'Estudis Catalans.

Ducrot, O. (1989). Logique, structure, enunciation. Paris: Les éditions de minuit.

Duden richtiges und gutes Deutsch. Wörterbuch der sprachlichen Zweifelsfälle (4th ed.). (1997). Mannheim: Dudenverlag.

Hansen, G. (1986). Kontrastive Analyse des Artikelgebrauchs im Dänischen und Deutschen. Copenhagen: Nyt Nordisk Forlag Arnold Busck.

KorpusDK. Web site: http://ordnet.dk/korpusdk

Oxford German Dictionary: German-English, English-German (3rd ed.). (2008). Oxford: Oxford University Press.

Rubattel, C. (1990). Polyphonie et modularité. Cahiers de Linguistique française, 11, 297-310.

Searle, J. R. (1990). Intentionality: an essay in the philosophy of mind. Cambridge: Cambridge University Press.

Van Leuven-Zwart, K. (1989). Translation and original: Similarities and dissimilarities, I. Target, 1(2), 151-181.

Van Leuven-Zwart, K. (1990). Translation and original: Similarities and dissimilarities, II. Target, 2(1), 69-95.

1 E.g., Paul explains that he wrote a letter to his putative father asking for money (Grass $2002 / 2007$, p. 20). It is a non-functional event; its only purpose is to show the narrator's ironic attitude towards his putative father.

2 E.g., he describes his putative father (Grass 2002/2007, p. 20) with the only objective to mock him.

3 E.g., he describes internet in a positive way (Grass 2002/2007, p. 133), with the intention to criticize it.

4 The use of an adjective instead of a genitive attribute ("Zuwendung des Vaters") is opposed to a natural style in German, and it is often used humorously. (Duden richtiges und gutes Deutsch).

5 There are nearly 70 instances of the idiom in the main corpus of Das digitale Wörterbuch der Deutschen Sprache (DWDS), and the co-text where they appear is often ridden with orality features. In the passage under study, the suppression of the first "a" strengthens its informal tone.

6 It appears nearly 2000 times in the KorpusDK, often in journalistic articles about law or economics. The most frequent words in its immediate co-text are "udgifter" ("expenses") and "effekten" ("the effect"). 
7 As Hansen (1986, p. 99) points out, an adjective (with an -ich ending) followed by a common noun in German is usually expressed through a compound in Dänisch ("faderopmaerksomhed"). In this case, the translator maintains the German construction, which adds a shade of oddness and pomposity to the sentence.

8 It appears some hundreds of times in the KorpusDK, mostly in opinion articles written in an informal tone. The co-text is often ridden with orality features (e.g. question/exclamation marks, polysyndeton).

9 "Lladregot" is a derivative word from "lladre" ("thief"). The suffix -ot added to a common noun results in a contemptuous word, often used as an insult. 